\title{
BIOCHEMICAL AND HISTOPATHOLOGICAL INVESTIGATIONS OF ANTIDIABETIC POTENTIAL OF POLYHERBAL FORMULATION IN ALLOXAN INDUCED DIABETIC RATS
}

\author{
Asra Iftikhar, Bilal Aslam*, Faqir Muhammad, Tanweer Khaliq, Muhammad Naeem Faisal, \\ Zia-ur-Rahman, Junaid Ali Khan and Wafa Majeed
}

\author{
Institute of Pharmacy, Physiology and Pharmacology, University of Agriculture, Faisalabad, Pakistan. \\ *Corresponding author's e-mail: cba933@gmail.com
}

\begin{abstract}
Herbal therapies always remain a potential source of glycemic control in diabetic patients. Plants or combination of plants improve the healing action and lessen the adverse effects compared to synthetic drugs. The present research was designed to evaluate antidiabetic potential of polyherbal formulation consisting of Sphaeranthus indicus, Caesalpinia bonduc, Bunium persicum, Artemisia absinthium, Cuminum cyminum, Swertia chirata, Gymnema sylvestra, and Citrullus colocynthis in alloxanized diabetic rats. Quantitative phytochemical, RP-HPLC, DPPH and in vitro alpha amylase analyses of formulation were performed. Rats were grouped into six groups ( $\mathrm{n}=15 /$ group) named as control, diabetic control, glibenclamide treated, Treated I, Treated II and Treated III. Hyperglycemic rats of treated groups I, II and III were administered polyherbal formulation at dose rate of 200,400 and $600 \mathrm{mg} / \mathrm{kg}$ respectively for 8 weeks after induction of diabetes with alloxan monohydrate (150, IP). The results have shown that alloxan significantly increased fasting blood glucose $(531.81 \pm 4.29)$ and serum glucose $(526.0 \pm 6.26)$ levels. However, 8-weeks treatment of hyperglycemic rats with polyherbal formulation significantly decreased the fasting blood glucose $(156.82 \pm 4.51)$, serum glucose $(148.8 \pm 4.04)$ and increased C-peptide and liver glycogen levels. The levels of ALT, AST, ALP, TAC and TOS were also restored towards normal. Histopathological analysis of pancreas also showed increase in size and number of pancreatic $\beta$ cells after polyherbal formulation treatment compared to diabetic group. This study shows that polyherbal formulation has antidiabetic potential as it can improve performance of pancreatic $\beta$ cells and insulin secretory capacity by reducing hyperglycemia and oxidative stress induced $\beta$ cells apoptosis.

Keywords: Alloxan monohydrate, hyperglycemia, RP-HPLC, liver glycogen, pancreas, histopathological analysis
\end{abstract}

\section{INTRODUCTION}

Diabetes mellitus is a chronic metabolic disorder attributed by hyperglycemia, glucosuria and negative nitrogen balance and mainly associated with absolute deficiency or decreased production of insulin (Gua et al., 2016). According to World Health Organization (WHO) estimates, the number of diabetic people is expected to increase up to 300 million by the year 2025 and $80 \%$ of diabetic population will be from low and middle-income countries (Osadebe et al., 2014). Previous experimental and clinical research investigations have reported that oxidative stress is most important cause of diabetes and diabetic complications. If free radical generation in the body increases or its removal from the cells reduces, it results in oxidative cellular damage. Diabetes mainly results from decrease in pancreatic beta ( $\beta$ ) cell mass due to reactive oxygen species (ROS) induced cellular damage (Donath et al., 2014).

Commonly used remedies for diabetes include insulin therapy and oral hypoglycemic agents such as biguanides, alpha glucosidase inhibitors and sulfonylureas (Tokajuk et al., 2015). However, long term use of these medicines is associated with adverse effects like drug resistance, hypoglycemia or hepatotoxicity. These hypoglycemic agents are also not able to normalize lipid profile in diabetic patients (Babu, 2016). That's why, it is important to find an alternative agent that can lessen apoptosis and increase insulin secretion from pancreatic $\beta$ cells with less/no adverse effects. Different research studies have identified the efficacy of plants and herbal formulations as potential hypoglycemic agents in the treatment of diabetes (Rezaei et al., 2015). The antidiabetic potential of plants is credited to their ability to restore the pancreatic $\beta$ cells function either by increasing insulin secretion and decreasing blood glucose concentration or by facilitating metabolites in insulin-dependent processes (Paoli et al., 2015).

The herbal formulations contain more than one active ingredient such as flavanoids, terpenoids, saponins, glycosides and alkaloids which have antioxidant, antihyperlipidemic and antidiabetic activities (Ramadan et al., 2017). These formulations act on different sites in the body and produce antihyerglcemic effect by increasing $\beta$ cells regeneration and insulin production, peripheral glucose utilization, liver and muscle glucagon content (Solanki et al., 2017). The present research study was designed to investigate the antidiabetic and pancreatic $\beta$ cells regenerative potential 
of polyherbal formulation consisting of Sphaeranthus indicus (Mundi boti), Caesalpinia bonduc (kranjwa magz), Bunium persicum (Kala zeera), Artemisia absinthium (Afsanteen boti), Cuminum cyminum (Safeed zeera), Swertia chirata (Chirata), Gymnema sylvestra (Ghurmar boti), and Citrullus colocynthis (Kortumma) from its anti-apoptotic and insulin secreting actions in alloxan induced diabetic rats. It would provide scientific basis for the development of potential natural curative agent for treatment of diabetes.

\section{MATERIALS AND METHODS}

Polyherbal formulation preparation: Polyherbal formulation was prepared by using fruits of Citrullus colocynthis and Caesalpinia bonduc, seeds of Cuminum cyminum and Bunium persicum, leaves of Gymnema sylvestra, Sphaeranthus indica, Artemisia absinthium, and Swertia chirata in equal ratio. Plants were shade dried, grinded and extracted by cold maceration method. The obtained extracts were concentrated under reduced pressure and mixed to prepare polyherbal formulation.

Quantitative phytochemical and RP-HPLC analysis: Polyherbal formulation was subjected to quantitative phytochemical analysis to determine the presence of polyphenols according to Folin-Ciocalteu method (Ahmed et al., 2014), total flavonoids by Aluminiun Chloride colorimetric method (Moonmun et al., 2017) and saponins (Senguttuvan et al., 2014). A precise and easy reverse phase high performance liquid chromatography (RP-HPLC) method was developed with some modifications for further assessment of different compounds present in herbal mixture extract (Seal, 2016).

Antioxidant and a-amylase inhibition assay: DPPH assay was performed to assess 1, 1-diphenyl-2-picrylhydrazyl stable free radicals (DPPH) scavenging affinity of herbal extract (Mensor et al., 2001). The in vitro $\alpha$-amylase inhibition activity was determined spectrophotometrically using acarbose as reference compound (Gella et al., 1997).

Experimental design: Ninety (90) adult Wister albino rats (180-200g) were kept in an animal room at Institute of Pharmacy, Physiology and Pharmacology, University of Agriculture, Faisalabad. Rats were randomly grouped into six groups, each consisting of 15 rats. Alloxan monohydrate (150 $\mathrm{mg} / \mathrm{kg}$ ) dissolved in normal saline was injected intraperitoneally to overnight fasted rats except control group for induction of diabetes. Group 1 was considered control and group 2 was diabetic control and group 3 (+ve control) was treated with $(10 \mathrm{mg} / \mathrm{kg})$ glibenclamide. Group 4 (Treated I), 5 (Treated II) and 6 (Treated III) were treated with 200, 400 and $600 \mathrm{mg} / \mathrm{kg}$ of polyherbal formulation for 8 weeks. The experiment was performed according to procedures of Graduate studies research board (GSRB).

Biochemical analysis: Commercially available glucometer (On.Call ${ }^{\circledR}$ Plus II) was used for the estimation of fasting blood glucose level from the tail vein of rats on weekly basis upto 8 weeks. After 8 weeks of treatment, the rats were slaughtered, blood samples were collected, allowed to clot and centrifuged at $4000 \mathrm{rpm}$ at $4^{\circ} \mathrm{C}$ for $10 \mathrm{~min}$. Resultant sera were stored at $-80^{\circ} \mathrm{C}$ until assayed. Serum glucose and C-peptide levels was determined by using commercially available kits (Catalogue \# AK00161 and 0030-70-1). Liver glycogen level was determined by method described by Plummer (1971) with slight modifications. Serum alanine aminotransferase (ALT), alkaline phosphate (ALP) and aspartate aminotransferase (AST) activities were estimated by using Randox reagent kits (Catalogue \# AL1200, AP8002, AS2800). Serum total oxidative stress (TOS) and total antioxidant capacity (TAC) were estimated by methods developed by Erel (2005) and Erel (2004) using spectrophotometer.

Histopathological Examination: The pancreas of rats were dissected out after animal sacrifice, fixed in $10 \%$ neutral buffered formalin (NBF) and embedded in paraffin. $5 \mu \mathrm{m}$ thick sections were stained with hematoxylin and eosin (H\&E) dye for microscopic investigation (Bancroft and Gamble, 2002).

Statistical analysis: All results were expressed as mean \pm SE. Statistical analyses were performed using one-way ANOVA followed by Duncan multiple range (DMR) test. $\mathrm{P} \leq 0.05$ was considered statistically significant.

\section{RESULTS}

Quantitative phytochemical analysis and characterization (spectral study) of polyherbal formulation: Results of quantitative phytochemical analysis have shown that aqueous extracts of plants and their combination (polyherbal formulation) have significant amount of phenolic compounds, flavanoids and saponins (Table 1).

Table 1. Total polyphenol, total flavonoid and saponin content of aqueous herbal extracts.

\begin{tabular}{lccc}
\hline Herabal extract & $\begin{array}{c}\text { Total } \\
\text { polyphenolic } \\
\text { content (mg } \\
\text { GAE/g sample) }\end{array}$ & $\begin{array}{c}\text { Total } \\
\text { flavonoid } \\
\text { content (mg } \\
\text { CE/g sample) }\end{array}$ & $\begin{array}{c}\text { Saponin } \\
(\%)\end{array}$ \\
\hline Citrullus colocynthis & 122.53 & 79.46 & 13 \\
Caesalpinia bonduc & 67.62 & 84.37 & 11 \\
Cuminum cyminum & 63.27 & 56.32 & 9 \\
Bunium persicum & 62.93 & 68.06 & 16 \\
Gymnema sylvestra & 113.21 & 87.82 & 26 \\
Sphaeranthus indica & 37.51 & 43.81 & 17 \\
Swertia chirata & 85.59 & 63.27 & 24 \\
Artemisia absinthium & 78.54 & 53.27 & 25 \\
Mixture(Polyherbal & 137.65 & 94.73 & 31 \\
formulation) & & & \\
\hline
\end{tabular}

GAE $=$ Gallic acid, $\mathrm{CE}=$ Catechin

RP-HPLC is an important separation technique used for the further quantitative assessment of phytoconstituents. HPLC 
spectra of different active compounds like quercitin, gallic acid, kampherol, vit $\mathrm{C}$ and cinamic acid present in polyherbal formulation are shown in Fig. 1. Retention times and concentrations of these compounds are presented in Table 2.

Table 2. Retention times and concentrations of active compounds present in polyherbal formulation extract.

\begin{tabular}{clc}
\hline Retention time & Compound & Conc.(ppm) \\
\hline 2.65 & Chromatotropic acid & 2.96 \\
3.04 & Quercitin & 16.94 \\
4.85 & Gallic acid & 10.32 \\
7.82 & Kampherol & 12.62 \\
22.64 & Vit.C & 9.84 \\
28.61 & Cinamic acid & 12.09 \\
\hline
\end{tabular}

DPPH and In vitro alpha-amylase inhibition assay: Different concentrations of herbal formulation extract showed significant DPPH free radical scavenging activity in concentration dependant manner. The higher antioxidant activity is reflected in a lower IC50 value (Table 3). According to the results, polyherbal formulation showed significant inhibition of alpha amylase enzyme. Polyherbal formulation at concentrations of $10,25,50,75$ and $100 \mu \mathrm{g} / \mathrm{ml}$ showed $27.1 \pm 0.1 \%, 39.2 \pm 0.3 \%, 45.3 \pm 0.3 \%, 61.2 \pm 0.7 \%$ and $75.3 \pm 0.5 \%$ inhibition of alpha amylase respectively and IC50 value was $52.74 \mu \mathrm{g} / \mathrm{ml}$ (Table 4 ).

Table 3. DPPH free radical scavenging activity of polyherbal formulation:

\begin{tabular}{ccc}
\hline Concentration $(\boldsymbol{\mu g} / \mathbf{m l})$ & \%inhibition & IC50 $(\boldsymbol{\mu g} / \mathbf{m l})$ \\
\hline 12.5 & $34.05 \pm 0.2 \mathrm{D}$ & 37.35 \\
25.0 & $44.39 \pm 0.3 \mathrm{C}$ & \\
50.0 & $57.37 \pm 0.3 \mathrm{~B}$ & \\
70.0 & $68.98 \pm 0.4 \mathrm{~A}$ & \\
\hline Values expressed as mean \pm SE $(\mathrm{n}=3)$
\end{tabular}

Table 4. In vitro Alpha-amylase inhibition assay of aqueous extract of polyherbal formulation.

\begin{tabular}{llc}
\hline Concentration $(\boldsymbol{\mu g} / \mathbf{m l})$ & \%inhibition & IC50 $(\boldsymbol{\mu g} / \mathbf{m l})$ \\
\hline 10 & $27.1 \pm 0.1 \mathrm{C}$ & 52.74 \\
25 & $39.2 \pm 0.3 \mathrm{CD}$ & \\
50 & $45.3 \pm 0.3 \mathrm{C}$ & \\
75 & $61.2 \pm 0.7 \mathrm{~B}$ & \\
100 & $75.3 \pm 0.5 \mathrm{~A}$ & \\
\hline
\end{tabular}

Values expressed as mean \pm SE $(n=3)$

Biochemical analysis:

Effect of polyherbal formulation on glucose homeostasis indicators (Fasting blood glucose, serum glucose, C peptide, liver glycogen): Fasting blood glucose and serum glucose levels were significantly $(\mathrm{P} \leq 0.01)$ increased in alloxan induced hyperglycemic rats. Serum C-peptide and liver glycogen contents were reduced in all groups of rats after induction of diabetes compared to control group. Use of glibenclamide in $+v e$ control group significantly $(\mathrm{P} \leq 0.01)$ restored the serum glucose, liver glycogen and C-peptide levels. However, use of graded doses of herbal formulation extract in treated groups I $(200 \mathrm{mg} / \mathrm{kg})$, II $(400 \mathrm{mg} / \mathrm{kg})$ and III $(600 \mathrm{mg} / \mathrm{kg})$ significantly $(\mathrm{P} \leq 0.01)$ recovered the fasting and serum glucose levels, liver glycogen and C-peptide contents (Fig. 2; Table 5).

Effect of polyherbal formulation on liver function markers and oxidative stress markers: Results have indicated significant increase $(\mathrm{P} \leq 0.01)$ in serum TOS and decrease in TAC of alloxanized hyperglycemic rats. Use of graded doses of herbal mixture extract in diabetic rats of groups $4^{\text {th }}, 5^{\text {th }}$ and $6^{\text {th }}$ produced significant $(\mathrm{P} \leq 0.01)$ amelioration by reversing the serum TOS and TAC levels near to normal at $8^{\text {th }}$ week of treatment. Serum ALT, ALP and AST levels were also significantly $(\mathrm{P} \leq 0.01)$ increased in all groups of rats after induction of hyperglycemia. Glibenclamide significantly $(\mathrm{P} \leq 0.01)$ restored serum TAC and TOS, ALT, ALP and AST

Table 5. Effect of Polyherbal formulation on serum glucose, C-peptide and liver glycogen level of alloxanized hyperglycemic rats.

\begin{tabular}{lrrrrrc}
\hline Parameters & \multicolumn{1}{c}{ Control } & Diabetic & +ve control & Treated I & Treated II & Treated III \\
\hline Serum Glucose $(\mathrm{mg} / \mathrm{dL})$ & $116.90 \pm 5.84 \mathrm{~d}$ & $526.00 \pm 6.26 \mathrm{a}$ & $135.58 \pm 3.05 \mathrm{c}$ & $246.70 \pm 2.51 \mathrm{~b}$ & $213.20 \pm 2.96 \mathrm{~b}$ & $148.80 \pm 4.04 \mathrm{bc}$ \\
Serum C- peptide $(\mathrm{ng} / \mathrm{mL})$ & $1.53 \pm 0.05 \mathrm{a}$ & $0.47 \pm 0.06 \mathrm{f}$ & $1.49 \pm 0.03 \mathrm{~b}$ & $1.03 \pm 0.05 \mathrm{e}$ & $1.21 \pm 0.05 \mathrm{~d}$ & $1.34 \pm 0.06 \mathrm{c}$ \\
Liver glycogen $(\mathrm{mg} / \mathrm{g})$ & $42.80 \pm 0.93 \mathrm{a}$ & $8.20 \pm 1.83 \mathrm{e}$ & $38.20 \pm 0.68 \mathrm{~b}$ & $22.20 \pm 0.58 \mathrm{~cd}$ & $29.60 \pm 0.51 \mathrm{c}$ & $29.60 \pm 0.51 \mathrm{c}$ \\
\hline
\end{tabular}

Values (mean $+\mathrm{SE})$ not bearing similar letters within a row differ significantly $(\mathrm{P} \leq 0.01)$.

Table 6. Effect of Polyherbal formulation on serum ALT, AST, ALP, TAC and TOS of alloxanized hyperglycemic rats.

\begin{tabular}{lrrrrrr}
\hline Parameters & Control & \multicolumn{1}{c}{ Diabetic } & +ve control & Treated I & \multicolumn{1}{c}{ Treated II } & \multicolumn{1}{c}{ Treated III } \\
\hline ALT $(U / L)$ & $36.15 \pm 1.47 \mathrm{e}$ & $86.39 \pm 5.59 \mathrm{a}$ & $41.52 \pm 2.98 \mathrm{~d}$ & $61.92 \pm 3.64 \mathrm{~b}$ & $54.59 \pm 2.49 \mathrm{bc}$ & $48.04 \pm 2.58 \mathrm{~cd}$ \\
AST $(\mathrm{U} / \mathrm{L})$ & $42.92 \pm 2.16 \mathrm{~d}$ & $137.04 \pm 5.64 \mathrm{a}$ & $45.20 \pm 1.95 \mathrm{c}$ & $74.69 \pm 1.64 \mathrm{~b}$ & $69.40 \pm 2.64 \mathrm{~b}$ & $51.40 \pm 1.72 \mathrm{bc}$ \\
ALP $(\mathrm{U} / \mathrm{L})$ & $114.40 \pm 3.60 \mathrm{~d}$ & $198.40 \pm 5.48 \mathrm{a}$ & $124.20 \pm 1.85 \mathrm{c}$ & $150.00 \pm 3.74 \mathrm{~b}$ & $144.40 \pm 2.94 \mathrm{bc}$ & $139.80 \pm 2.80 \mathrm{bc}$ \\
TOS $(\mu \mathrm{mol} / \mathrm{L})$ & $10.10 \pm 0.49 \mathrm{~d}$ & $24.87 \pm 0.95 \mathrm{a}$ & $14.55 \pm 0.37 \mathrm{c}$ & $18.62 \pm 0.58 \mathrm{~b}$ & $17.45 \pm 0.36 \mathrm{bc}$ & $15.21 \pm 0.38 \mathrm{c}$ \\
TAC $(\mathrm{mmol} / \mathrm{L})$ & $1.95 \pm 0.05 \mathrm{a}$ & $0.47 \pm 0.05 \mathrm{f}$ & $1.86 \pm 0.05 \mathrm{~b}$ & $1.02 \pm 0.05 \mathrm{e}$ & $1.36 \pm 0.05 \mathrm{~d}$ & $1.71 \pm 0.05 \mathrm{c}$ \\
\hline
\end{tabular}

Values (mean+SE) not bearing similar letters within a row differ significantly $(\mathrm{P} \leq 0.01)$. 
levels in +ve control group. However, treatment of diabetic groups $4^{\text {th }}, 5^{\text {th }}$ and $6^{\text {th }}$ of rats with 200,400 and $600 \mathrm{mg} / \mathrm{kg}$ of aqueous herbal formulation extract potentially decreased the serum levels of ALT, AST and ALP in comparison to diabetic group producing dose dependant therapeutic effect (Table 6).

Histopathological results: Histopathological analysis of control group revealed normal pancreas having active islets with round nuclei and abundant cytoplasm (Fig. 3a). Photomicrograph of pancreas of alloxan induced diabetic rat showed severe congestion, variable sized pancreatic islets, massive reduction in number of $\beta$ cells and inflammatory cellular infiltration compared to control group (Fig. 3b). Glibenclamide treatment showed active pancreas with less congestion and mild lymphocytic infiltration (Fig. 3c). Photomicrograph of pancreas of polyherbal formulation treated group I $(200 \mathrm{mg} / \mathrm{kg})$ showed mild degree of necrotic changes and improved vasculature (Fig. 3d). Use of $400 \mathrm{mg} / \mathrm{kg}$ of aqueous herbal mixture extract in alloxanized hyperglycemic rats produced marked improvement in cellular injuries as evident from partial restoration of islets and $\beta$ cells mass (Fig. 3e). While highest dose of polyherbal formulation produced significant recovery by decreasing congestion and necrotic changes in $\beta$ cells and increasing active $\beta$ cells population (Fig. 3f).

\section{DISCUSSION}

Diabetes mellitus is a chronic metabolic disorder and associated with impaired metabolism of proteins, fats, and carbohydrates. Commonly used oral hypoglycemic agents have few detriments including drug resistance or drug interactions (Babu, 2016). In the modern era, herbal formulations have gained importance due to their efficacy and fewer side effects compared to the synthetic drugs. These effects are due to the presence of different phytochemicals like flavanoids, saponins, terpenoids which are reported to have antidiabetic and antioxidant potential (Uzor and Osadebe, 2016). These advantages have led the people to move toward herbal preparations for disease treatment and prevention, as they are claimed to display synergistic, potentiative, and agonistic/antagonistic effects (Subhasree $e t$ al., 2015).

Quantitative phytochemical analysis indicated the presence of secondary metabolites such as polyphenolics, flavanoids and saponins in aqueous herbal formulation extract. In present research study, RP-HPLC method was used for quantification of quercetin, vit C, gallic acid, kaempferol and cinnamic acid in aqueous herbal formulation extract. Phenolic compounds have antioxidant, antimicrobial and anticancer properties (Yadav et al., 2015). Flavonoids are very important and diverse group of phytochemicals having potent antioxidant potential. Quercetin (flavanoid) has also been reported to decrease the blood sugar level, hepatic gluconeogenesis, glycogenolysis and increase glucose uptake resulting in anti- hyperglycemic potential (Hossain et al., 2016). According to one of the previous research studies, saponins are responsible for producing anti-diabetic effect by increasing glucose uptake in striated muscles and decreasing blood glucose level (Sugihara et al., 2000).

Antioxidant potential of natural products is very important due to the harmful effects of free radicals on biological systems (Gaikwad et al., 2011). The results have proved that herbal mixture extract significantly $(\mathrm{P} \leq 0.01)$ scavenge DPPH free radicals and it could be a good source of antioxidants due to the presence of phenolic compounds and flavanoids. These results are supported by one of previous studies in which Bauhinia vahlii extracts showed better DPPH free radical scavenging potential (Sowndhararajan and Kang, 2013). The results of in vitro alpha amylase studies showed that polyherbal formulation significantly inhibited alpha amylase activity. These results are supported by one of the previous research studies in which Amaranthus spinosus inhibited alpha-amylase activity because phytochemicals like flavanoids may bind to a specific binding site of the key digestive enzymes such as $\alpha$-amylase (Teng and Chen, 2017). In present research study, protective role of polyherbal formulation in alloxanized hyperglycemic rats was investigated. It is reported that alloxan produces discriminatory necrosis of the pancreatic $\beta$-cells resulting in depletion of insulin secretion. The poisonous actions of alloxan on $\beta$ cells include essential sulphydryl (-SH groups) oxidation, glucokinase enzyme inhibition, free radicals generation and instability in intracellular calcium homeostasis (Das et al., 2012). According to the results, treatment of diabetic rats of treated groups I, II and III with graded doses of polyherbal formulation produced dose dependant reduction in fasting blood glucose and serum glucose levels. The antihyperglycemic potential of formulation may be due to presence of phytoconstituents like quercitine, kampherol and gallic acid. These phytoconstituents act synergistically and produce antidiabetic effect by reducing cellular oxidative stress, increasing insulin release from pancreatic $\beta$ cells, stimulating glycogenesis, and increasing pheripheral glucose absorption (Fu et al., 2013).

Measures of serum C-peptide level have been considered as important marker of insulin secretion (Akinlade et al., 2014). Present research study indicated significant $(\mathrm{P} \leq 0.01)$ decrease in serum C-peptide and liver glycogen levels after induction of diabetes. The decrease in liver glycogen and C-peptide concentrations was due to low level of glycogen synthetase and decreased availability of insulin (Khatune et al., 2016). Use of glibenclamide and herbal mixture extract in diabetic rats significantly $(\mathrm{P} \leq 0.01)$ raised serum $\mathrm{C}$-peptide and liver glycogen levels resulting in improved glucose metabolism. Serum levels of ALT, AST and ALP were significantly increased in rats after induction of diabetes. Use of herbal mixture extract potentially $(\mathrm{P} \leq 0.01)$ decreased the level of liver function markers. These observed effects may be due to 
antihyperglycemic, antioxidant and hepatoprotective properties of flavanoids and terpenoids which are reported to prevent the release of intracellular enzymes of liver in addition to membrane stabilizing effects. (Zarei et al., 2015). Hyperglycemia increases the production of reactive oxygen species (ROS) and depletes cellular antioxidant defense capacity that contributes towards the $\beta$ cells apoptosis in diabetes (Almalki et al., 2016). In the present research study, we observed significant $(\mathrm{P} \leq 0.01)$ increase in total oxidative stress (TOS) which is an important marker of lipid peroxidation, whereas total antioxidant capacity (TAC) was significantly $(\mathrm{P} \leq 0.01)$ decreased in hyperglycemic rats. However, use of graded doses of aqueous herbal formulation extract in alloxanized hyperglycemic rats of groups $4^{\text {th }}, 5^{\text {th }}$ and $6^{\text {th }}$ significantly $(\mathrm{P} \leq 0.01)$ lowered the oxidative stress and potentially returned the antioxidant capacity (TAC). These results suggest that polyherbal formulation may protect the $\beta$ cells of pancreas through the inhibition of lipid peroxidation and restoring antioxidant system. Consistent with previous studies, flavanoids (quercetin, kampherol) and saponins (gymnemic acid) present in polyherbal formulation have anti apoptotic and free redical scavenging activities. These properties make these compounds potent antioxidant and antihyperglycemic agents (Basha and Sankaranarayanan, 2016).

According to histopathological evaluation, pancreas of diabetic group of rats showed small size of islets of langerhans, destruction of $\beta$ cells indicating necrotic changes. Diabetic rats treated with $400 \mathrm{mg} / \mathrm{kg}$ of polyherbal formulation have pancreatic paranchyema with normal appearance, however islet of langerhans were less in number and $\beta$ cells were destroyed indicating pycnotic changes. Treatment of hyperglycemic rats with highest dose $(600 \mathrm{mg} / \mathrm{kg})$ of polyherbal formulation recovered the degenerative changes and showed normal morphology of pancreatic $\beta$ cells with regular outlines indicating active pancreas. These changes may be due to antistress, antidiabetic and regenerative potential of phytoconstituents (flavonoid e.g., quercetin, terpenoids, alkaloids, saponins), minerals such as $\mathrm{Zn}$ and vitamins such as vitamin $\mathrm{C}$ in polyherbal formulation. These compounds defend and improve the viability and regeneration of $\beta$ cells and subsequent release of insulin (Monday and Uzoma, 2013; Nosiri et al., 2016).

Conclusion: It is concluded from present research study that polyherbal formulation has the potential to reverse hyperglycemia through antioxidant and regenerative potential as evidenced by increased $\beta$ cell mass in polyherbal formulation treated diabetic rats.

\section{REFERENCES}

Ahmed, D., M. Fatima and S. Saeed. 2014. Phenolic and flavonoid contents anti-oxidative potential of epicarp and mesocarp of Lageneriasicerariafruit: a comparative study. Asian Pac. J. Trop. Med. 7:249-55.

Akinlade, A., A. Ogbera, O. Fasanmade and O. Olamoyegun. 2014. Serum C-peptide assay of patients with hyperglycemic emergencies at the Lagos state university teaching hospital (LASUTH), Ikeja. Int. Arch. Med. 7:50.

Almalki, W.H., E.S.A. Arafa, A.Y. Abdallah, A.M. Mahfoz, A.O. Osman, H.A.A. El-Latif and I. Shahid. 2016. Zinc chloride protects against streptozotocin-induced diabetic nephropathy in rats. Pharmacol. Pharm. 7:331-342.

Babu, N.R. 2016. Studies on the evaluation of antidiabetic and antioxidant activities using some selected medicinal plants. Int. J. Herb. Med. 4:21-24.

Bancroft, J.D. and M. Gamble. 2002. Theory and Practice of Histological Techniques, $5^{\text {th }}$ Ed. Churchill Livingstone, Edinburgh, UK.

Basha, R.H. and C. Sankaranarayanan. 2016. $\beta$ Caryophyllene, a natural sesquiterpene lactone attenuates hyperglycemia mediated oxidative and inflammatory stress in experimental diabetic rats. Chem. Biol. Interact. 245:50-58.

Das, J., V. Vasan and P.C. Sil. 2012. Taurine exerts hypoglycemic effect in alloxan-induced diabetic rats, improves insulin-mediated glucose transport signaling pathway in heart and ameliorates cardiac oxidative stress and apoptosis. Toxicol. Appl. Pharmacol. 258:296-308.

Donath, M.Y., C. Hess and E. Palmer. 2014. What is the role of autoimmunity in type 1 diabetes? A clinical perspective. Diabetologia 57:653-655.

Erel, O. 2004. A novel automated direct measurement method for total antioxidant capacity using a new generation, more stable ABTS radical Cation. Clin. Biochem. 37:277-85.

Erel, O. 2005. A new automated colorimetric method for measuring total oxidant status. Clin. Biochem. 38:110311.

Fu, Z., E.R. Gilbert and D. Liu. 2013. Regulation of Insulin Synthesis and Secretion and Pancreatic Beta-Cell Dysfunction in Diabetes. Curr. Diabetes Rev. 9:25-53.

Gaikwad, S.A., G.S. Kamble, S. Devare, N.R. Deshpande and J.P. Salvekar. 2011. In vitro evaluation of free radical scavenging potential of Cassia auriculata L. J. Chem. Pharm. Res. 3:766-772.

Gella, F.J., G. Gubern, R. Vidal and F. Canalias. 1997. Determination of total and pancreatic alpha amylase in human serum with 2-chloro-4-nitrophenyl-alpha-Dmaltotrioside as substrate. Clin. Chim. Acta 259:147160. 
Guo, J., J. Wanga, S. Song, Q. Liu, Y. Huang, Y. Xu, Y. Wei and J. Zhang. 2016. Sphallerocarpus gracilis polysaccharide protects pancreatic $\beta$ cells via regulation of the bax/bcl-2, caspase-3, pdx-1 and insulin signaling pathways. Int. J. Biol. Macromol. 93:829-36.

Hossain, M.K., A.A. Dayem, J. Han, Y. Yin, K. Kim, S.K. Saha, G.M. Yang, H.Y. Choi and S.G. Cho. 2016. Molecular mechanisms of the anti-obesity and antidiabetic properties of flavonoids. Int. J. Mol. Sci. 17:569.

Khatune, N.A., B.M. Rahman, R.K. Barman and M.I. Wahed. 2016. Antidiabetic, antihyperlipidemic and antioxidant properties of ethanol extract of Grewia asiatica Linn. bark in alloxan-induced diabetic rats. BMC Complement. Altern. Med. 16:295.

Mensor, L.L., F.S. Menezes, G.G. Leitao, A.S. Reis, T.S. dos Santos, C.S. Coube and S.G. Leitao. 2001. Screening of Brazilian plant extracts for antioxidant activity by the use of DPPH free radical method. Phytother. Res. 15:127-30.

Monday, O.M. and A.L. Uzoma. 2013. Histological changes and antidiabetic activities of Icacina trichantha tuber extract in beta-cells of alloxan induced diabetic rats. Asian Pac. J. Trop. Biomed. 3:628-633.

Moonmun, D., R. Majumder and A. Lopamudra. 2017. Quantitative phytochemical estimation and evaluation of antioxidant and antibacterial activity of methanol and ethanol extracts of Heliconia rostrata. Indian J. Pharm. Sci. 79:79-90.

Nosiri, C., S. Okereke, C. Anyanwu, C. Chukwuduruo and C. Nwankw. 2016. Responses of liver and pancreatic cells to ethanolic seed extract of Aframomum Melegueta in alloxan-induced diabetic rats. J. Med. Plants Studies 4:112-116.

Osadebe, P.O., E.U. Odoh and P.F. Uzor. 2014. The search for new hypoglycemic agents from plant. Afric. J. Pharm. Pharmacol. 8:292-303.

Paoli, P., A. Caselli, G. Camici and P. Cirri. 2015. Effect of natural compounds on insulin signaling. Curr. Med. Chem. 22:80-111.

Plummer, D.T. 1971. Practical Biochemistry, $3^{\text {rd }}$ Ed. McGraw Hill Book Comp., England.

Ramadan, B.K., M.F. Schaalan and A.M. Tolba. 2017. Hypoglycemic and pancreatic protective effects of Portulaca oleracea extract in alloxan induced diabetic rats. BMC Complement. Altern. Med. 17:37.

Rezaei, A., A. Farzadfard, A. Amirahmadi, M. Alemi and M. Khademi. 2015. Diabetes mellitus and its management with medicinal plants: A perspective based on Iranian research. J. Ethnopharmacol. 175:567-616.
Seal, T. 2016. Quantitative HPLC analysis of phenolic acids, flavonoids and ascorbic acid in four different solvent extracts of two wild edible leaves, Sonchus arvensis and Oenanthe linearis of north-eastern region in India. J. Appl. Pharm. Sci. 6:157-166.

Senguttuvan, J., S. Paulsamy and K. Karthika. 2014. Phytochemical analysis and evaluation of leaf and root parts of the medicinal herb, Hypochaeris radicata L. for in vitro antioxidant activities. Asian Pac. J. Trop. Biomed. 4: 359-367.

Solanki, P.S., K.V. Chaudhary, V.H. Kanbi and I.N. Patel. 2017. Effect of herbal formulation (Churn) on type 2 diabetic Patients. J. Pharmacogn. Phytochem. 6:307-310.

Sowndhararajan, K. and S.C. Kang. 2013. Free radical scavenging activity from different extracts of leaves of Bauhinia vahlii Wight and Arn. Saudi J. Biol. Sci. 20:319-25.

Subhasree, N., A. Kamella, I. Kaliappan, A. Agrawal and G.P. Dubey. 2015. Antidiabetic and antihyperlipidemic activities of a novel polyherbal formulation in high fat diet/streptozotocin induced diabetic rat model. Indian J. Pharmacol. 47:509-513.

Sugihara, Y., H. Nojima, H. Matsuda, T. Murakami, M. Yoshikawa and I. Kimura. 2000. Antihyperglycemic effects of gymnemic acid IV, a compound derived from Gymnema sylvestre leaves in streptozotocindiabetic streptozotocin diabetic mice. J. Asian Nat. Prod. Res. 2:321-327.

Teng, H. and L. Chen. 2017. $\alpha$ Glucosidase and $\alpha$-amylase inhibitors from seed oil: a review of liposoluble substance to treat diabetes. Crit. Rev. Food Sci. Nutr. 57:3438-3448.

Tokajuk, A., E. Krzyzanowska-Grycel, A. Tokajuk, S. Grycel, A. Sadowska and H. Car. 2015. Antidiabetic drugs and risk of cancer. Pharmacol. Rep. 67:1240-1250.

Uzor, P.F. and P.O. Osadebe. 2016. Antidiabetic activity of the chemical constituents of combretum dolichopetalum root in mice. Excli J. 15:290-296.

Yadav, S., P. Nand and R.K. Gupta. 2015. Formulation and phytochemicals characterization of polyherbal (Tinospora cordifolia, Gymnema sylvestre, Pterocarpus marsupium and Acacia arabica) antidiabetic compressed tablet lozenges. J. Pharmacogn. Phytochem. 4:244-253.

Zarei, A., G.H. Vaezi, A.A. Malekirad and M. Abdollahi. 2015. Effects of ethanol extract of Salvia hydrangea on hepatic and renal functions of streptozotocin-induced diabetic rats. Avicenna J. Phytomed. 5:138-147. 